\title{
Conflict-Generating Factors of Doctor-Patient Communication in Russian-Language Discursive Practices
}

\author{
Oxana S. Issers* \\ Dostoevsky Omsk State University \\ Omsk, Russian Federation
}

Received 10.08.2021, received in revised form 22.08.2021, accepted 14.09.2021

\begin{abstract}
The article studies the causes of conflict situations between a doctor and a patient in the communication, associated with the problems of using the language code and the compliance of communicative and ethical norms. The research focuses on conflictgenerating factors caused by the violation of the patient's right to information about the state of health, which include, in particular, the volume and details of such information, as well as the forms it was provided. Methods of verbalizing the information about the patient's health are discussed, taking into account the requirements of accessibility and sensitivity. The author examines problematic situations caused by the «non-linguistic» nature of legal regulation in the field of doctor-patient communication. The aim of the study is to identify conflict-generating factors of communication in the medical field, which lead to a violation of not only ethical, but also legal norms of communication between doctors and patients. The empirical base was formed by questioning the patients. The study also used blogosphere, social media materials, and personal interviews with patients. The analysis of sociolinguistic data made it possible to identify 4 conflict-generating factors: 1) the availability of information; 2) volume (details) of information, 3) delicacy / indelicacy; 4) the quality of the doctor's feedback for the patient.

As a result of the study, conclusions were drawn that allow to linguistically interpret the communicative failure that arose in the process of communicating with the doctor. This gives reason to develop criteria for communicative violations that are potentially conflict ones and have legal effect.
\end{abstract}

Keywords: medical discourse, conflict-generating factor, doctor-patient communication, medical ethics, availability of information, delicacy, discursive practices, communicative failure.

The study was carried out with the financial support of the grant from St. Petersburg State University (project number 75254082 «Modeling of Russian megalopolis citizens' communicative behavior in social, speech and pragmatic aspects using artificial intelligence methods»).

(C) Siberian Federal University. All rights reserved

* Corresponding author E-mail address: isserso@mail.ru

ORCID: 0000-0003-4027-6346 
Research area: philology.

Citation: Issers, O.S. (2021). Conflict-generating factors of doctor-patient communication in russian-language discursive practices. J. Sib. Fed. Univ. Humanit. soc. sci., 14(10), 1567-1580. DOI: 10.17516/1997$1370-0840$

\title{
Конфликтогенные факторы общения врача с пациентом в русскоязычных дискурсивных практиках
}

\author{
O.C. Исcерс \\ Омский государственный университет им. Ф. М. Достоевского \\ Российская Федерация, Омск
}

\begin{abstract}
Аннотация. В статье обсуждаются причины конфликтных ситуаций в общении врача и пациента, связанные с проблемами использования языкового кода и соблюдением коммуникативных и этических норм. В фокусе исследования находятся конфликтогенные факторы, обусловленные нарушением права пациента на информацию о состоянии здоровья, которые включают, в частности, объем и состав такой информации, а также формы ее предоставления. Обсуждаются приемы вербализации информации о состоянии здоровья пациента с учетом требований доступности и деликатности. Автор рассматривает проблемные ситуации, обусловленные «нелингвистическим» характером правового регулирования в сфере общения врача с пациентом. Цель исследования - выявление конфликтогенных факторов общения в медицинской сфере, которые приводят к нарушению не только этических, но и правовых норм коммуникации врача с пациентом.

Эмпирическая база сформирована путем анкетирования пациентов. В исследовании также использованы материалы блогосферы и социальных сетей и личные интервью с пациентами. Анализ социолингвистических данных позволил выявить 4 конфликтогенных фактора: 1) доступность информации; 2) объем (состав) информации, 3) деликатность / неделикатность; 4) качество обратной связи врача с пациентом.

В результате исследования сделаны выводы, позволяющие лингвистически интерпретировать коммуникативную неудачу, возникшую в процессе общения с врачом. Это дает основания для разработки критериев коммуникативных нарушений, потенциально конфликтогенных и имеющих правовые последствия.
\end{abstract}

Ключевые слова: медицинский дискурс, конфликтогенный фактор, общение врача с пациентом, деонтология, доступность информации, деликатность, дискурсивные практики, коммуникативная неудача.

Исследование выполнено при финансовой поддержке гранта Санкт-Петербургского государственного университета (проект № 75254082 «Моделирование коммуникативного поведения жителей российского мегаполиса в социально-речевом и прагматическом аспектах с привлечением методов искусственного интеллекта»).

Научная специальность: 10.00 .00 - филологические науки. 


\section{Introduction}

Communication in the medical field is an essential element of social experience of a healthy as well as an unhealthy person. Health itself ranks among vital values due to the fact that all aspects of a man's social existence are determined by the health level. That is why effective communication with doctors and other medical staff is of importance for everyone because it provides productive and healthy life to the fullest extent.

Besides qualifications, medical communication is controlled by ethic standards and norms of law. Ethical aspect of this communication implies shaping verbal and non-verbal communication in view of deontology basics (empathy and tolerance) on the basis of humanism and benevolence as well as adhering to three conditions such as acceptance, optimism, and dignity strengthening (Matveeva, 2014: 120). Medical ethics issues, various aspects of medical staff communication, communicative barriers in doctor-patient communication are viewed in the frame of biomedical ethics (Biomedical ethics and communication in health care, 2018). Besides, ethical aspect of communication is closely connected to observance of linguistic and communicative regulations as the part of the given lingoculture (Matveeva, 2014).

Legal aspect of doctor-patient interaction is subject to Russian legislation and the Constitution of the Russian Federation, which entrenches each Russian citizen's right to healthcare maintenance and medical care (Art. 41). The patient's right to information is the most important type of rights. Here are such rights as the rights to medical aid provision (including the cases of choosing a doctor or a healthcare organisation), information on factors influencing health, information on physical condition and the data protection right (Art. 13, para. 1, 5 и 7 of Part 5 Art, 19, Part 7 Art. 21, art. 22 и 23 Federal Law No. 323-FZ «On fundamental healthcare principles» of 21.11.2011) ${ }^{1}$.

The right to information guarantees that a patient can take own decisions on health issues. Information of health condition gives the

Collection of Laws of the Russian Federation. 2011. No. 48. Art. 6724. Available at: https://base.garant.ru/74710282/ choice for a patient: whether to get medical intervention or not ${ }^{2}$. The necessary circumstance of accepting any medical intervention is Informed Voluntary Consents of a patient (IVC). Refusal from medical operation shall also be followed by providing the preliminary information on any possible consequences of it. This means that a patient's right to information is the reflection of constitutional rights including dignity right, human inviolability, private life, and personal and family confidentiality (see in (Issers, Fedorova, 2020)).

True accomplishment of this right is closely and firmly interrelated to the aspects of linguistics and communication, which are not so fully regulated in accordance with law. It is thereof the reason and case of communication failures and in some particular cases even lawsuits, which are the subject of unaccounted conflict-generating factors in doctor-patient communication.

\section{Statement of the problem}

When considering conflict situations in doctor-patient communication a number of questions requiring linguistic competence arise. In most cases they are related to problems with the use of language code and communicative norms compliance. As a rule, they do not go beyond the reflection of this communication act participants (doctors and patients). However, transition of conflict situations in the legal sphere and their consideration within the framework of linguistic forensic examination are not excluded.

In many cases conflictogenic factors are the cases of violation of the patient's right to information on the physical condition, the volume and composition of such information as well as the way it is given. Thus, the law provides for the composition of information on a citizen's physical condition (defined in Part 1, Art. 22, Federal Law «On fundamental healthcare principles») according to which everyone has the right to get information available in a healthcare organisation about physi-

\footnotetext{
Federal Law N323-FZ «On fundamental healthcare principles» of 21.11.2011 (ed. 02.07.2021) (as amended and supplemented, entered into force on 13.07.2021). Available at: http:// www.consultant.ru/document/cons doc LAW 121895/
} 
cal condition, medical tests results, diseases, diagnosis, prognosis, methods of providing medical care, the related risks, possible types of medical intervention, its consequences and results (Federal Law, 2011). The above list is not limiting and it contains the most significant information. Therefore, if the healthcare organisation has more information on a patient's health status, it is also to be provided when requested.

Problematic situations also concern the way a doctor verbalizes information on a patient's physical condition. Legal regulation of this issue implies two requirements. One of them is general and the other one is formally given a special nature. The general one is that information about physical condition must be provided in an accessible form. The special one goes for cases of unfavourable prognosis of a disease progression when the information must be given in a delicate form (with respect for its accessibility to whom it is addressed). As referred to in (Issers, Fedorova, 2020), the terms «accessible» and «delicate» are evaluative. They do not lend themselves to the full formalization. In addition, it should be noted that the requirements mentioned are not limited to cases of an unfavourable prognosis of a disease progression and they relate to the entire process of doctor-patient interaction.

Among the most common problematic situations stipulated by non-linguistic character of legal regulation in the sphere of doctorpatient communication are the following ones:

1. A question on accessible form raises the linguistic problem of qualifying the chosen verbalization mode of medical information with respect to a patient's knowledge and linguistic competence. One more topical question here is that on information exhaustiveness. Thus, prescribing some treatment and medications, a doctor chooses the information scope. Using regulations determining the information to give in different cases are not common for Russian medical practice.

2. A question on delicacy refers to Art. 22 of the Federal Law No. 323-FZ «On fundamental healthcare principles» of 21.11.2011, which demands a delicate way of providing information. This requirement preconditions eth- ical and linguistic definitions of delicacy notion and gradation of its favourable prognosis of the disease progression euphemization.

3. A question on a patient's will («Information on physical condition is not to be given against a patient's will») is not legally regulated. How can it be possible to identify the fact that a patient doesn't want to go into own health details?

4. The way a doctor renders verbal anamnesis in written form involves decoding (terminological compression and transformation of data given by a patient), which raises a question on original and written texts equivalents.

5. Doctor-patient communication tonality implies the way to establish a violation of ethical norms like sarcasm/irony, overfamiliarity, being thuggish etc.

So, the purpose of the study is to find out conflict-generating factors of doctor-patient communication which lead to ethical and legal norms of this communication. This calls for identifying the sources and generating the evidence base of the study.

\section{Methods}

The core problem of establishing the facts of ethical, communicative, and legal waiver consists in verbalization of communication and absence of inspectors. The data collection by means of overt observation is in practice of linguistic studies on medical communication (Akaeva, 2007; Barsukova, 2006, 2007; Maiboroda, 2017, 2021). However, it is questionable by two reasons. Communication ethics excludes the third party that is not the part of medical staff. Practically speaking, it is unlikely to generate a representative selection in all respects under tight deadlines. Thus, the material analysis involves interview and questionnaire methods as well as flashback notes in question. It is understood that these notes are not authentic due to the interpretation modes and additional pieces going beyond original texts, abstracts. (It is exemplified in psychological and legal books, for example, in researches by A. Loftus on witness flashbacks remodelling (Hawk, 2008: 193-205)). Moreover, this method helps to identify the key points for the study. 
The results of first-time material collection make it possible to 1) give a linguistic interpretation of the communicative failure arisen in doctor-patient communication; 2) develop the criteria of communication violations that are potentially conflict-generating and implying the legal effects; 3) develop a linguo-expert analyzing technique that helps to identify the linguistic marks of communication violations which can be afterwards adjudicated as offence.

Thus, the study points out linguistically relevant recommendations about what a doctor should not say meaningfully and in which way he should provide potentially traumatic content to the patient. In cases of conflict this will allow using the citizens' official statements in trial, linguistic expertise if what was said to them is reflected literally, as well as different types of notes which were made during an appointment.

Based on the above-mentioned conditions of the research framework formation, a questionnaire was developed for the patients. Its purpose is to find out the main conflictgenerating factors which directly or indirectly violate human rights to information. The respondents to the questionnaire used Google forms which suggested questions on communication situations, in which they performed as patients and were not satisfied with the content of communication or its form (sometimes both factors were noted). More than 50 questionnaires of the respondents aged 18-60+ were processed.

Besides the questionnaire data, healthcare materials found in forums, groups and other social media as well as the author's private interviews with the patients were analyzed in the given study. As well as in questionnaire, the material is a flashback and often contains estimated comments.

\section{Discussion}

The questions of the questionnaire related to communicative problems of communication in the medical field were formulated in such a way as to establish which patients' expectations for the volume of information, its content and form of presentation were not satisfied, which ethical and legal requirements were not met. The survey touched upon 4 main aspects: 1) the availability of information; 2) the volume of information; 3) the delicacy; 4) the quality of a doctor's feedback to a patient.

\section{Accessibility of information \\ as a communicative problem \\ of medical communication}

The availability of the given information to the addressee is one of the main conditions for successful communication and is determined by the proportion between the new, the original, and the well-known. According to the French researcher A. Mol, accessibility is achieved due to the abundance of information - «full or partial repetition of a message, an explanation that serves to check and correct the adequate perception of the message» (cit. ex: (Vikulova, Sharunov, 2008: 71)).

The problem of information accessibility is the subject for discussion from the perspective of both patients and doctors. Particularly, it is related to the form of Informed Voluntary Consent which is signed by a patient in Russia and other countries. D. Sarkisyan, the journalist, considers this form to be a formality, stating that «a person, giving a voluntary consent to get medical interventions, doesn't estimate properly what operations a doctor is going to perform. This problem exists all over the world, and it negatively affects the results of treatment. However, it is real to cope with it» (Sarkisyan, 2021). The pediatrician who responded to the journalist's request expresses his opinion that the text of the Informed Voluntary Consent contains many incomprehensible words: «And even if it is hard to imagine complications from spirography or electroencephalography, a person has the right to at least know what this means!» The head physician of the clinic, the ENT specialist, Vladimir Korshok notes that «the text of the Informed Voluntary Consent, offered to the patient, is a complex document, full of legal and medical terms, containing tricks which appear herein after "corrections by a lawyer'» (Ibid.).

To find out the influence of the accessibility factor on the effectiveness of communication with a doctor, question 1 was included in the questionnaire. 
Give, if you can, the examples when the information received from the doctor about your disease and treatment was incomprehensible due to the use of certain terms and general misunderstanding.

More than half of the respondents noted that they did not face such situations. At the same time, they note that the request for information in case of misunderstanding is the area of the patient's responsibility.

I have never had that because I have the habit of clarifying and asking again about the things that are not clear at once. I reread all the conclusions and discuss them with the doctor. And I communicate with a constant circle of professional doctors ${ }^{3}$.

The child was diagnosed with stenosis. I had never heard of such a disease, so I demanded an explanation.

However, the answers also contain critical assessments of the language code chosen by a doctor. But this is not the only problem that can occur. Accessibility is closely related to the volume of information: if there is not enough information, some of what has been said remains incomprehensible.

Sometimes a doctor can bombard you with terms without explaining their meaning, but I rarely faced this. Once a doctor didn't explain whether my disease will stop after taking some medicine. I wasn't sure if I face this again. And I found that quite incompetent.

The doctor told about the advantages of injections over pills using rather incomprehensible terms.

This is a case of occlusion, a common thing. You can take or not something for the vessels. The case is not that serious.

There is a special communicative issue between a doctor and a patient on the doctor's choice of a role strategy in relation to a patient who ranges from «ignorant» to «enlightened», almost a specialist. The doctor's strategies range from a disregard for the patient's knowledge and experience («mind your own business») to an educational enthusiasm aimed at providing maximum information

\footnotetext{
3 Hereinafter, the answers are given in the normative spelling and punctuation format. The style has been retained by the author.
}

along with irrelevant detailing of the disease and treatment.

Doctors do not like to talk about diseases and diagnoses with patients who are then surprised by the alphanumeric designations of the type of HHD or hypertensive heart disease, EH or essential hypertension (not only the abbreviation is not clear, but also what it is, what special type of hypertension is meant, how it arises and how to treat it) in my case.

Once I could not immediately say if my mother had COPD (Chronic Obstructive Pulmonary Disease). It was not at all clear what it really was: a disease or some kind of medical device.

Such situations constantly arose at the dentist, a candidate of sciences, university teacher. She spoke to me as a senior student who understands terminology. And she did not try to put that into simple language as ordinary doctors from clinics do. Everyone else always tried to reformulate ${ }^{4}$, if they saw a misunderstanding. It is impossible to give examples, since the text remained incomprehensible and, accordingly, unreproducible.

An example of overestimated role expectations in relation to an «enlightened» patient is the desire to give a complete picture of the disease with comments, for example, on X-ray results.

At an appointment with an orthopedist with an ankle ligament injury the doctor showed a picture and explained how the joint works and what happened for about $10 \mathrm{~min}$ utes, naming all the bones and tendons, as in a lecture on anatomy. In this case, there is a discrepancy between a doctor's intention and a patient's expectations: it is more important to know what the prognosis of treatment is and when a patient will begin to walk without pain than the ankle structure.

A popular method of explanation in the medical field is metaphorization. Thanks to television, this rhetorical device has become very popular in health education. However, being infatuated with it, as noted by one of the informants, can also lead to communication failure:

\footnotetext{
4 The informant notes that there is an effective strategy for increasing information availability.
} 
It is annoying when doctors start using metaphors.

Apparently, the metaphorical form used in a doctor's explanations is presented to welleducated patients as a signal of unequal relations. The relevance of this technique is easily revealed through the request: Do you want me to explain figuratively or scientifically?

Thus, it is possible to identify the linguistic markers of information availability, the absence of which can cause a conflict. These are constructions of explanation and clarification accompanying the use of medical terms, as well as taking into account the addressee's factor from the point of view of awareness in medicine. The latter is found in the corresponding requests: Do you know what it is? You know ...? Should I explain it to you? Do you want me to comment on the X-ray picture? etc.

\section{Composition and volume of information}

as a factor of successful communication

One of the key factors of successful doctor-patient communication is the volume of information received by the patient. In this regard, the following question was included in the questionnaire (2).

2. Give, if you can, the examples when the volume of information was not enough (it was not explained how to take medications, what the restrictions are, what possible side effects can be there, what the prognosis of the disease is, etc.).

$80 \%$ of the responses prove that a patient did not receive the required amount of information. This primarily concerns side effects and possible complications.

Once my ENT specialist prescribed IRS19 (Immune Rehabilitation Spray), a contraindication to which was autoimmune thyroiditis indicated in my medical card. The doctor did not ask if I have any diseases that may be a contraindication. Not a single doctor speaks about side effects and prognosis, according to my observations.

Information about the restrictions and side effects of taking medications was not explained in any of the visits to a doctor.

The doctor prescribed me a medicine for blood pressure and did not warn me that a cough could be a side effect. And I have bronchial asthma. When I visited this doctor again, I said that I was choking when coughing, and he replaced the medicine with another one ... Not even apologizing.

Professional doctors sometimes prescribe too many different medications and examinations without explaining their meaning. Doctors almost do not talk about the side effects of drugs, you have to read about them in the instructions and be horrified.

During pregnancy I was diagnosed with oligohydramnios and insufficiently large size of the child. They sent me to get IV without explaining its effectiveness and exact need, what side effects might be there and how it would affect the child.

Further, in terms of relevance, there is incomplete information about the need for additional examinations, for example, in case of an unfavorable prognosis:

When I was given the results of histology at the First State Academy named after I.P. Pavlov, they did not mention that the removed polyp is adenomatous and it was worth visiting oncologists and show the tests. If there was someone who did not understand what was said, this could be a problem.

The informants' responses repeatedly indicate the lack of clarification about the prescribed drugs, procedures, and correct medication intake.

Doctors' explanations about taking statins, threats to health in case of refusal to take them, justification of the dose and the qualification of this dose against the background of possible ones are not enough.

When prescribing statins, the doctor did not talk about possible side effects. The same is with drugs for pressure, some are not allowed with metabolic syndrome, which a relative has. They never say anything. You have to read everything and look for information by yourself.

The mother-in-law was prescribed medication, but nothing was explained (perhaps she did not remember) that one drug should be taken 30 minutes before meals, and the other during meals. She took all the medicines after eating. 
As a rule, this applies to prescriptions. Doctors indicate, for example, that the medicine should be taken once a day, but they do not indicate after or before meals or during that. Or if two drugs are interchangeable - which is the first to take?

At one of the last appointments the doctor wrote out prescriptions without explaining that the dosage needed to be adjusted, and also prescribed medications, without specifying that this was only for one part of the treatment.

It was said to dilute ceftriaxone with distilled water. Nothing more was said. Pharmacists gave lidocaine and said nothing. The first injection was very painful. Then the understanding came.

The gynecologist did not warn that a certain drug in a certain dose would bring the menopause closer. Fortunately, the pharmacist at the pharmacy said this!

Any patient is interested, first of all, in terms of treatment and its result. The lack of relevant information is considered by patients as a communicative miscalculation.

Almost always general practitioners, when you apply to them for compulsory medical insurance, do not explain how and when the disease will stop.

The problem of the absence or incomplete information about the procedures is also revealed in situations when the examination of the patient or his/her treatment is carried out without explanations / comments from the doctor.

The doctor asked if my eye pressure had been measured before. I had previously been at a preventive appointment with a doctor, but I was not aware of which examinations the doctor conducted by means of certain manipulations. The doctor did not comment on what tasks he solved during the examination. I had to answer: I don't know ...

The doctor in the day hospital states, «We are going to give you Milgamma injections» (Not explaining what it is or why).

Lack of necessary information is not always perceived by the patients as a violation of their legal right. More often they turn to other sources, such as the Internet.

If a similar problem arises, I find all the missing information on the Internet.
A number of informants are of the opinion that the request for missing information is the responsibility of the patient him/herself:

In case of insufficient information, the patient always asks again and again and receives information then! Disease prognosis is more often used so that the patient can feel the seriousness of the situation, i. e. to achieve maximum compliance.

However, in our opinion, this does not disclaim the doctor's responsibility: a request for information is possible only in a situation where the patient has at least some knowledge about the disease.

Clarification of the details is the responsibility of the patient himself. If he does not know anything about targeted therapy and so on, then he will not be able to ask questions.

At the same time, there are often cases when the patient's awareness or desire to obtain additional information is perceived negatively by the doctors:

The doctor rudely interrupted if I had a need to clarify some points during the discussion of treatment details. The doctor's intonation indicated his extreme irritation.

Thus, in modern conditions of medical communication, the determination of the degree of information completeness and its availability depends entirely on the doctor's professional competence. At the same time, the lack of information specified in part 1 of Art. 22 of the Federal Law «On the Fundamental healthcare principles» as a citizen's right to information, may have a conflict-generating nature and serve as a basis for legal proceedings. The problem is that the list of information provided to a patient is not mandatory for doctor-patient interaction (there are no scripts prescribing the verbalization of the information listed in the law) and, therefore, not mentioning the aspects of treatment and prognosis of the disease may be motivated by the absence of a patient's request.

\section{Delicacy in doctor-patient communication}

The problem of delicacy is one of the key ones in the aspect of communication effectiveness and it is considered within the framework of the categories of politeness and tact (Sternin, 
2003; Larina, 2009; Kharchenko, 2010; Issers, 2019). In medical communication, empathy and respect for a patient's dignity is a requirement of biomedical ethics. Delicacy takes on particular importance in case of an unfavorable prognosis of the disease (this is regulated by Art. 22 of the Federal Law «On fundamental healthcare principles»), but it is by no means limited to such situations ethically.

From a linguistic perspective, delicacy is formed due to the general communicative strategy of a doctor (a drive to «soft» communication with a patient), as well as specific tactics that require him to choose language means appropriate for communicating with a patient (a doctor's strategies can be studied in (Barsukova, 2006, 2007; Akaeva, 2007; Maiboroda, 2021)). A special role in this case is played by the choice of direct or indirect speech acts, as well as the preference for direct or euphemistic nominations.

To identify indelicacy signs (tactlessness, disrespectful attitude), a number of questions were included in the questionnaire, the purpose of which is to establish in which situations a patient feels dignity infringement.

3. Give, if you can, an example when a doctor's communication was disrespectful, indelicate. How was this expressed?

4. Give, if you can, the examples of when you didn't want to know something that a doctor told you, or would like him to tell you about it, but indirectly, in a softer, more gentle form.

5. Give, if you can, the examples when a doctor's tone seemed inappropriate to you (emphasized familiarity, sarcasm / irony / mockery etc.)

The informants give numerous examples of situations where, in their opinion, the doctor's communicative behaviour did not correspond to the principles of politeness and delicacy. The analysis of the survey data allows us to identify the linguistically relevant markers of indelicate speech behaviour.

One of the most common markers of disrespect is a patient's presumption of guilt and the implications of dishonesty and ignorance:

After a severe form of pneumonia (75\% of lung damage), a pulmonologist at the district clinic, extending the sick leave, said that I hadn't got better for too long. It was spoken in such a tone and was accompanied by such a look that I had the feeling that I was a malicious simulator who only wants to extend the sick leave, and I did not come with the hope to get medical help. At the same time, CT scans showed 25-20\% of lung damage. The pulmonologist said with irritation that she did not agree with the conclusion that the CT doctor wrote. To my words that a CT scan is not like an X-ray, but $3 D$, volumetric, the percentages are automatically calculated there, blackouts are visible with the naked eye, she replied, "You do not understand anything, so mind your own business».

There was a case: I came to an appointment with an endocrinologist with the question of how to stop weight gain. What I got was rough, I was told to eat less. And to the printed food diary, which proved that I was «eating» 1200-1500 calories in the corridor in a balanced mode, the doctor reacted briefly, "It's nonsense».

I came down with coronavirus. After recovering, I came to the doctor for referrals for control tests. In response to all the complaints about feeling unwell, the doctor said, "everything is fine, everyone is the same». I got the necessary referrals only after a complaint to the head of department.

A tactless question can serve as a marker of the patient's presumption of guilt:

Here is an example of an appointment with an epileptologist:

A patient says, "My relative has been suffering from epilepsy since the age of 21». A doctor replies, "Did you drink yesterday?» Seeing the anamnesis and looking through the documents (CT of the brain, EEG (electroencephalography), MRI), this question is incorrect (a relative has been suffering from hydrocephalus since childhood).

At the appointment with a gastroenterologist: "How did you grow such a stone?! It looks as if it has been specially cultivated» (stone in the gallbladder).

We are seeing an endocrinologist. The problem is the child's overweight. The doctor says, "What have you come with again (we visited this doctor 2 years ago)?». 
I replied, "We are overweight ... will you prescribe anything or ask to do tests?»

The doctor says, "... you were there 2 years ago. What have you come for? You haven't lost weight, why have you come? What do you want from me?»

And I say, "Perhaps you will ask to have the tests done to establish the cause and prescribe some drugs?»

Explication of a patient's age or any other characteristics in the context of treatment prospects can be inherently offensive:

My mother ( 80 years old) told me that last week she finally received a card to a cardiologist, who, only seeing her, an elderly woman, said, "Well ... they go here all the time ... It's natural for you to feel like that. How old are you? This is outrageous! Old people are annoying».

The case with the mother-in-law. Last year she fell just slipping on the ice and broke her hip. She was 82 years old. The granddaughter took her to the emergency room. A doctor examined her and said, «Nothing can be done at your age, go home and stay in bed. The pain will pass, but you will not walk. At your age, such operations are no longer performed. And if they are, then they are usually unsuccessful. Our relatives went home crying and suffering from an unbearable pain in the pelvis and leg. Thank God, we found a doctor who successfully performed the osteosynthesis operation, and after 2 months the mother-in-law ran on her own two feet, without a hook, into the apartment located on the third floor.

A gynecologist says, "You don't have to worry about "women's problems» anymore, that's it for people of your age».

Such a disappointing prognosis can be possible in relation to patients of different ages, but they are especially traumatic for the elderly.

Offensive statements that lower the status of a patient in general and in relation to the doctor in particular are not uncommon in the situation when the patient is accompanied by his relatives. In this case, indelicacy can be due to both disregard for a patient and those who accompany him or her.

The doctor turns to the accompanying one, "Why are you here? A patient could have come alone». This was incomprehensible to us, because my relative with epilepsy does not remember his seizures. What is more, the same doctor asks about seizures, "What seizures do you have? With a fall or with an aura?» My relative is not so well prepared for such a talk and does not understand what he is being asked about, not knowing this terminology, not being able to know about own attacks as if those can be seen from the outside!

Ambulance on call. The husband is lying, feeling bad. I am explaining the situation instead of him. An ambulance doctor (not a paramedic) suggests, «Maybe he will say that?»

When a doctor communicates with a very elderly, deaf people, a doctor completely switches to communicating with the accompanying relative, ignoring the presence of an old man, without addressing him in any way.

At an appointment with an epileptologist when a doctor directly addresses a patient with epilepsy and hydrocephalus, "Yes, YOU (highlighted by the informant-O.I) no longer have any brain, it's only water instead of it».

The doctor wonders, «Do you have such a problem in your family (overweight)?» I reply, «Yes, we are all overweight: grandmother, father, and I myself have gained many kilos after giving birth to a child». The doctor says, «Well, she hasn't given birth yet (a daughter, who is 14 years old, is here too)».

The issue of the delicate form can be considered in the context of the choice of euphemization / dysphemisation tactics. In addition, a patient's dissatisfaction can be caused by a doctor's tone, which a patient perceives as familiar, ironic and even sarcastic, derisive. Question 5 (see above) was motivated by the clarification of these circumstances of medical communication.

The therapist says, "So why are you so obese? Do you just want to lie down and not get up at all? You need to eat less!»

Indelicacy at a doctor's appointment may be due to discussions with relatives in the presence of a minor patient on taboo topics in Russian linguoculture.

My daughter sprained her ankle while riding a scooter. We visited a private traumatologist after going to a trauma center. There 
was no traumatologist at the local polyclinic that day. The doctor writes an anamnesis and says, "When did you become overweight?» I said that we had come because of a different problem, my daughter had sprained her ankle, jumping on a scooter on a bump. The daughter needs to have a fixation bandage. The doctor concludes, "So, obesity (my daughter is sitting at the reception...). How did you give birth to a child?» (This is a question for me, in the sense of this being difficult or not).

Problems of indelicate communication may be associated with the fact that a doctor does not take into account the interpretive potential of what is said. A patient tends to seek a subtext and interpret a doctor's words, usually with a negative prognosis.

After taking the drug you will go for an MRI of the head, you do not need to see me, immediately sign up for a gamma knife (the doctor implies a negative prognosis of the examination).

The doctor examined the cervical spine by computed tomography and said, "Well, now you are tired, go home and rest. We'll discuss it tomorrow». (The doctor appeared to be in a hurry, and the patient considered the situation so serious that it warrants discussion the next day. The patient survived a terrible night while awaiting for the diagnosis).

The doctor's speech behavior in critical situations deserves a certain consideration:

There was a case with grandfather. He had bronchial asthma. During the next attack I had to call an ambulance. The ambulance doctor, seeing the grandfather, began to shout, «He's dying! He is dying!» Grandpa died.

One of the factors that traumatize the patients and their loved ones is a negative prognosis, which does not have sufficient grounds, but it is motivated by the medical workers' marketing tasks.

At an appointment with a children's cardiologist, they came to the next ultrasound procedure of the heart (observations about an open oval window). We had an ultrasound of the heart, an ECG (electrocardiogram) done for our daughter.

When we came for scoring, the doctor said, "She's in big trouble». I asked, "What trouble?» The doctor frightens me saying, «We urgently need to watch blood electrolytes: ions of calcium, magnesium, potassium! Urgently! Look at her! She's obese!» (my 13 year old daughter is here). I ask, "What's happened? Are there any abnormalities in the ultrasound scan? ECG? We were told that everything was fine (the doctor who did the ultrasound scan and the one who has the appointment were different) Why should we take these tests? We have come for a different reason. As far as I know, electrolytes are monitored if patients are under intensive care». The doctor replies, "You don't know anything. She has big problems. Do you think that she will always be with you all her life?! No, she will soon leave you, being a typical teenager. It's lucky for you that she's here with you for now, but soon it will be over. I understand that you work, she is overweight, and you have no time for her. Where have you been all this time?» As a result, the doctor did not explain to me what the problem was. Since the center was private, and the doctor was the director of this center, she wanted to intimidate me so that I would agree to have a bunch of unnecessary tests done, which show nothing. The daughter was observed by various cardiologists about the congenital open oval window, and the window is very small, which did not affect the functional state of the child's heart.

Thus, indelicacy in the medical field has many manifestations, but in certain cases it can be established in the presence of typical linguistic markers. These include the presumption of the patient's guilt and its implications, tactless questions, explication of a patient's age and other characteristics as grounds for an unfavorable prognosis of treatment, offensive statements that lower the status of a patient accompanied by the relatives. These semantic indicators should be attributed to signals of indelicate communication with the patients in the medical field.

\section{«I Hear You»: a patient's feedback}

\section{as a factor of successful medical communication}

Situations of receiving / not receiving a feedback from a doctor, when there are discrepancies between a patient's expectations and a doctor's reactions, are conflict-generating 
by nature. In this regard, question 6 was included in the questionnaire.

6. Have you encountered a situation when the information you provided was ignored by a doctor, but you thought it was important for the diagnosis? How did you find out that a doctor did not take this information into account?

The informants' responses provide the examples where the information they had provided was not perceived as relevant for the diagnosis and treatment and, as a result, was ignored.

A doctor prescribed the drug «Dona» for the treatment of joints. I warned about an allergy to Lidocaine, so I bought a pack of ampoules without reading the instructions, but it was good that I read it before the injection: it included Lidocaine!

I can't take cough syrups that contain alcohol. I told the doctor about it. I was prescribed such a medicine.

In certain situations, the conflict is due to the difference in professional and nonprofessional perception / experience of the disease: everything that happens seems to be relevant to establish the cause of the disease for a patient, therefore he or she provides all the details of its course, while for a doctor this information may not have any significance for the right diagnosis.

My dad had a microstroke. The ultrasound of the brain vessels showed there was a blood clot. The doctors in our city hospital, which is also a vascular center! did not pay attention to this, they prescribed him an exercise bike (a blood clot in the head and a microstroke!). After the first lesson, the father's blood pressure rose to 220/120, a second stroke occurred (within 5 days from the moment of admission to the hospital). The information about the thrombus according to the ultrasound examination was unimportant for them.

A conflict-generating factor can be the discrepancy between the intentions of a patient and a doctor, when a doctor does not respond to a patient's request, but implements own version of diagnosis and treatment.

My husband and I are at a cardiologist's appointment (blood pressure). Having measured the pressure (and it was 140/90, pulse
98), the doctor says, "What drugs are you taking?» I explain that my husband is taking this and that, but we want to find a different drug, as this one causes drowsiness. The doctor says, "Of course, it is because of the age... weight. You need to go in for sports, you need to lose weight. How much do you weigh?» My husband answers, "105 kg». The doctor replies, "This is too much, you must weigh 80 for your height». I say, "Yes, yes, that's a problem. But we would like to choose a drug, since we are not going to lose weight now». The doctor concludes, "I have recently had a group of athletes, basketball players. Do you know what their pulse is? It is 30-40 beats per minute».

Thus, the effectiveness of communication with a doctor is determined, along with other things, by his professional skills of listening and interpreting a patient's intentions. Conflict situations arise both due to inattention to the information provided by a patient or those accompanying ones, and due to the lack of communication skills of feedback and checking the recipient's understanding of what the doctor said.

\section{Conclusion}

Communicative success and communication failure have peculiar manifestations in different types of discourse. The general principles of cooperative communication, presented in the concept of P. Grice and other researchers, require concretization in relation to the specifics of interaction in a particular social sphere.

For communication in the medical field, the effectiveness of doctor-patient interaction is determined by a patient's right to information enshrined in Russian legislation (Federal Law «On fundamental healthcare principles»), professional ethics and adherence to communicative norms inherent in a particular linguistic culture. However, in real medical practice determination of the degree of information completeness, its availability and the strategy choice for verbalizing the diagnosis and the prospects for treatment depends entirely on the professional competence of a doctor. Due to insufficient linguistic study of these aspects, there are often conflict situations that can serve as a basis for legal proceedings. 
As a result of the study, four conflictgenerating factors were established, due to the choice of the language code and the communicative strategy of a doctor in communicating with a patient: 1) availability of information; 2) volume of information; 3) delicacy / indelicacy; 4) the quality of a doctor's feedback to a patient. They make it possible to linguistically interpret the main reasons for communicative failures that arise in the process of communicating with a doctor, and provide grounds for the development of criteria for communicative violations, potentially conflict-generating and having legal consequences.

\section{References}

Akaeva, E.V. (2007). Kommunikativnye strategii professional'nogo meditsinskogo diskursa: avtoreferat dis. ... kand, filol. nauk [Communicative strategies of professional medical discourse: author's abstract of PhD thesis]. Omsk, $22 \mathrm{p}$.

Biomeditsinskaia etika i kommunikatsii v zdravookhranenii: uchebno-metodicheskoe posobie [Biomedical ethics and communication in health care: teaching aid] (2018). Vitebsk, VGMU, 310 p.

Barsukova, M.I. (2006). Taktiki diagnostiruiushchei strategii meditsinskogo diskursa [Diagnostic strategy tactics in medical discourse], In Saratovskii nauchno-meditsinskii zhurnal [Saratov Journal of Medical Scientific Research], 2, 3-7.

Barsukova, M.I. (2007). Meditsinskii diskurs: strategii i taktiki rechevogo povedeniia vracha: avtoreferat dis. ... kand. filol. nauk [Medical discourse: strategies and tactics of a doctor's speech behavior: author's abstract of $\mathrm{PhD}$ thesis]. Saratov, $21 \mathrm{p}$.

Federal'nyi zakon ot 21.11.2011 N323-FZ (red. ot 02.07.2021) «Ob osnovakh okhrany zdorov'ia grazhdan v Rossiiskoi Federatsii» (s izm. idop., vstup. v silu s 13.07.2021) [Federal Law N323-FZ of November 21, 2011 (as amended on July 2, 2021) «On fundamental healthcare principles» (as amended and supplemented, entered into force on July 13, 2021)] (2011). Available at: http://www.consultant.ru/document/cons_doc_ LAW_121895/

Hawk R. R. (2008). 40 issledovanii, kotorye potriasli psikhologiiu [40 Studies That Shook Psychology]. St. Petersburg, Praim-Evroznak, 193-205.

Issers, O.S. (2019). Rechevoe manevrirovanie kak lingvodidakticheskaia problema v obuchenii russkomu iazyku kak inostrannomu [Speech maneuvering as a linguodidactic problem in teaching Russian as a foreign language]. Russkoe slovo v mnogoiazychnom mire: Materialy 14 Kongressa MAPRIaL (g. NurSultan, Kazakhstan, 29 aprelia - 3 maia 2019 goda) [The Russian word in the multilingual world: Proceedings of the 14 Congress of MAPRIaL (Nur-Sultan, Kazakhstan, April 29 - May 3, 2019)]. St. Petersburg, MAPRIaL, 1074-1078.

Issers, O.S., Fedorova, M. Yu. (2020). Potentsial sudebnogo rechevedeniia v obespechenii realizatsiii zashchity prava patsienta na informatsiiu. [The potential of judicial speech in ensuring the implementation and protection of the patient's right to information]. Mezhdunarodnye $i$ natsional'nye tendentsii i perspektivy razvitiia sudebnoi ekspertizy: sbornik dokladov 2 Mezhdunarodnoi nauchnoi konferentsii (g. Nizhnii Novgorod, 21-22 maia 2020 g.) [International and Russian trends and prospects for the development of forensic examination: collection of papers of the 2 International Scientific Conference (Nizhny Novgorod, May 21-22, 2020)]. Nizhny Novgorod, NNGU, 150-158.

Kharchenko, V.K. (2010). Sovremennaia povsednevnaia rech' [Modern everyday speech]. 2 edition, Moscow, Izdatel'stvo LKI, 184 p.

Larina, T.V. (2009). Kategoriia vezhlivosti i stil' kommunikatsii. Sopostavlenie angliiskikh i russkikh lingvokul'turnykh traditsii [Category of politeness and communication style. Comparison of English and Russian linguocultural traditions]. Moscow, Rukopisi Drevnei Rusi, 512 p.

Matveeva, T.F. (2014). Eticheskii aspect rechevogo obshcheniia «vrach - patsient» kak kliuchevaia tema kursa «Kul'tura rechi vracha» [The ethical dimension of verbal communication «doctor-patient» as a key theme of the course «The culture of speech of the doctor»], In Vestnik RUDN, seriia Voprosy obrazovaniia: iazyki i spetsial'nost' [RUDN Bulletin, series Educational issues: languages and specialty], 4, 118-123. 
Maiboroda, S.V. (2017). Meditsinskii diskurs: sovremennye teoretiko-metodologicheskie podkhody i perspektivy issledovaniia [Medical discourse: modern theoretical and methodological approaches and research prospects], In Kommunikativnye issledovaniia [Communication Studies], 1 (11), 63-75.

Maiboroda, S.V. (2021). Rechevye strategii vracha v usloviiakh kollegial'noi i avtoritarnoi modeli kommunikatsii doktora i patsienta: skhozhdeniia i protivorechiia: avtoreferat dis. ... kand, filol. nauk [Doctor's speech strategies in the context of a collegial and authoritarian model of communication between a doctor and a patient: coincidence and contradiction: author's abstract of PhD thesis]. Saratov, $22 \mathrm{p}$.

Sternin, I.A. (2003). Vezhlivost' kak kommunikativnaia kategoriia [Politeness as a communicative category], In Kommunikativnoe povedenie [Communicative behavior], 17, 22-47.

Sarkisyan, D. (2021). Khotite po-nastoiashchemu ponimat', kak vrach budet vas lechit'? [Do you want to really understand how the doctor will treat you?]. Available at: https://meduza.io/feature/2021/08/12/ hotite-po-nastoyaschemu-ponimat-kak-vrach-budet-vas-lechit-togda-pochemu-vy-podpisyvaete-formuinformirovannogo-soglasiya-ne-chitaya

Vikulova, L.G., Sharunov, A.I. (2008). Osnovy teorii kommunikatsii: praktikum [Fundamentals of the theory of communication: workshop]. Moscow, ACT MOSKVA, Vostok-Zapad, 316 p. 